\title{
Soil Profile Based Land Suitability Study for Jute and Lentil Using AHP Ranking
}

\author{
Chiranjit Singha and Kishore C. Swain ${ }^{*}$
}

Dept. of Agricultural Engineering, Institute of Agriculture, Visva-Bharati, Sriniketan, West Bengal (731 236), India

\author{
Corresponding Author \\ Kishore C. Swain \\ e-mail: kishore.swain@visva-bharati.ac.in
}

\author{
Article History \\ Article ID: AR1869 \\ Received in $29^{\text {th }}$ March, 2018 \\ Received in revised form $19^{\text {th }}$ May, 2018 \\ Accepted in final form $5^{\text {th }}$ June, 2018
}

\begin{abstract}
The land use suitability evaluation leading to fine-tuning of crop selections and rotations are very important in optimising the land and labour productivities enhancing higher cropping intensities, producing better crop yield. The Analytical Hierarchy Process (AHP) technique coupled with GIS software environment can be a unique tool for better land suitability studies. The AHP technique is used for land suitability study in Hooghly District, West Bengal, India for existing deep rooted crops. The study area covering nearly 300 ha has been classified based on soil nutrient level with randomly selected fifty plot based soil sample analysis. The pairwise comparison matrix based ranking is carried out considering the importance of each parameter for jute and lentil crop in the region. The area, based on top soil layer could be classified as 'highly suitable' class of $6.5 \%$ area and 'not suitable' class of $2.5 \%$ area; for deep soil layer 'highly suitable' class occupied $10.3 \%$ of area and 'marginal suitable' class nearly $52.2 \%$ of area. The analysis revealed that in the study area for lentil, top layer only $3.0 \%$ classified as 'not suitable' but this class contribute nearly $7.2 \%$ in deep layer. The areas unsuitable for jute crop may be dedicated for lentil and other crops. This analysis will be immensely helpful for selecting tap root crops.
\end{abstract}

Keywords: GIS, AHP, land suitability, jute, lentil

\section{Introduction}

With the increasing population the pressure on the limited agricultural resource is ever increasing. The total population in India is projected to be 1.62 billion by 2050 (NCP, 2013). Sustainable agriculture guided by modern technologies like precision agriculture, land suitability etc. can enhance crop production. Agriculture and allied sectors contribute $13.9 \%$ of Gross Domestic Product (GDP) (2014-15) (Press Information Bureau, 2014-15) and play an important role in the Indian economy where around $70 \%$ of the rural households depend on agriculture (Kekane, 2013). Jute is an important cash crop across the world (Kumar, 2017). However, jute ecosystems are currently faced with numerous issues, such as poor crop establishment, unsuitable soil and land conditions, water scarcity, biotic and environmental stresses, and inefficient agronomical practices, which result in low returns to the farmers (Bag et al., 2015). Pulse crops are popular because of their importance as a source of protein and ability to fix atmospheric nitrogen $(\mathrm{N})$, and thus improve soil fertility. Additionally, for lentil, one of the pulse crops, India is the second largest producer and lead consumer in world (Singh and Singh, 2014).

Geographical Information System (GIS) has become very useful tools for the management of dynamic agricultural resource. Land evaluation is a process of predicting land suitability over time according to the specific types of use (Lee and Yeh, 2009; Martin and Saha, 2009; Sonneveld et al., 2010). Agriculture farmland suitability assessment is described as the process of estimation of land performance when utilized for alternative types of agriculture (He et al., 2011; Mu, 2006; Prakash, 2003). Baja et al. (2007) found two general types of land suitability evaluation scenarios: qualitative and quantitative. In qualitative approach, it may be possible to assess land potential in qualitative terms, such as highly suitable, moderately suitable, or not suitable. In the next approach, quantitative estimation of land suitability is given by numeric indicators. Land suitability evaluation is therefore generally evaluated by matching needs of biophysical/ecological, political and socio-economic parameters for the particular uses with properties and qualities of land types (FAO, 1985).

Agricultural-land suitability estimation is a prerequisite for getting optimum utilization of the available farm land resources for sustainable agricultural system (Perveen et al., 2007). FAO (1993) recommended 5 suitability groups such as highly suitable, suitable, marginally suitable, marginally unsuitable and permanently unsuitable. Land suitability is the potential of a particular type of land to support a particular use, and the process of land suitability evaluation involves 
the estimation and grouping of particular land areas based on their suitability for a defined use (Prakash, 2003).

It is required for decision makers to determine the quality of land for agricultural application and is intended as a decision and planning system (Elsheikh et al., 2013). The spatial and temporal pattern changes of cropland are required to understand the important parameters and the functional impacts of the agricultural landuse. These applications have been used by a number of researchers (Martinez-Casasnovas et al., 2005; Sood et al., 2017; Panigrahy et al., 2004) for land suitability analysis.

Analytical Hierarchy Process (AHP) is one of the promising methods used for the farmland suitability analysis based on each criterion through quantitative analysis (Chen et al., 2010). Pair wise comparison method is utilized to estimate the overall weight of each criteria or element. Integration of AHP and GIS assists in decision support by creation of suitability maps (Cengiz and Akbulak, 2009; Duc, 2006). GIS is utilized as a decision maker tool for the site suitability analysis and for progress activities (Khahro et al., 2014; Singha and Swain, 2016). Landuse suitability mapping and its evaluation is one of the most useful applications of the GIS (Javadian et al., 2011).

The main objective of the current study is to identify the most suitable areas for deep rooted crops, such as jute and lentil cultivation, based on physio-chemical properties on homogenous alluvial soils in Tarakeswar block in the Hooghly district region of West Bengal, India, using GIS-AHP digital mapping technique.

\section{Materials and Methods}

\subsection{Selection of study area}

This study was carried out in Tarakeswar block in the Hooghly district region of West Bengal. Geographical location of the district is between $23^{\circ} 01^{\prime} 20^{\prime \prime}$ to $22^{\circ} 39^{\prime} 32^{\prime \prime}$ North Latitude and $88^{\circ} 30^{\prime} 15^{\prime \prime}$ to $87^{\circ} 39^{\prime} 32^{\prime \prime}$ East Longitude. The total area of Hooghly district is $3149 \mathrm{~km}^{2}$. The underlying parent material within the study area consists primarily of quaternary alluvial deposits. Alluvial soils, formed by the Damodar-Hooghly river as accumulated sediments deposited at different times. The study area lies at an elevation of approximately 0-40 $\mathrm{m}$ (MSL). Major portion of the district (58.5\%) is under very gently sloping land. The area is forms flat plains and there is remarkable topographical homogeneity. The average annual rainfall of the district varies from $1200 \mathrm{~mm}$ to 1700 $\mathrm{mm}$. respectively. Predominance of fertile soils, land and adequate water resources in the study area are the key factors facilitating intensive agriculture in the study area (NBSS and LUP, 2001). The important kharif crops are rice, jute, and rabi crops are potato, mustard, pulse (lentil) and different types of vegetables. Boro paddy is also widely cultivated in irrigated areas. Canal, tube well and The Kana Nadi drainage stream of Hooghly river supplies the required irrigation for the crops in the study area (NBSS and LUP, 2001).

Open series map developed by Survey of India, 2011 was used for creating base map. Open series map sheet no. F45K1(79B/1) covering the five revenue villages, (such as: Aligori, Basudebpur, Bajitpur, Jothsombhu and Kolaikundu) of Tarkeswar block, Hooghly district, West Bengal, India was selected for study. The scale of the Map was 1:50,000 in UTM projection system with WGS-1984 datum. The base map is created by digitizing the mentioned topographical map in Arc GIS 10.1 (ESRI, Redlands, California USA) software environment. Around nine ground control points (GCPs) were collected using eTrex 20 GPS Receiver (Garmin Ltd., Olathe, Kansas, USA) for image registration of the study area. The features such as, study area boundary, road network including railway track, canal network and ponds etc. has been mapped. The railway track passing the study area connects between Howrah and Tarakeswar city. The total study area is around 300 ha. Most of the study area is under canal irrigation system.

\subsection{Soil sampling}

Soil samples were obtained from the study area GPS coordinate point order in onset monsoon. The total 50 soil samples were collected randomly from soil horizon layers, 0-15 cm (top), and 30-45 cm (deep) depth epically by taking into consideration the textural variation using auger examinations. The soil layer of $15-30 \mathrm{~cm}$ is not considered for analysis as the soil properties may be overlapping with top layer as well as deep soil layer causing redundancy in data. The samples were transported with sample ID to the laboratory to determine mechanical and chemical composition of soils.

\subsection{Chemical analysis}

The soil samples were analyzed for some common soil productivity attributing parameters viz. $\mathrm{pH}$, Soil Texture $(\mathrm{ST})$, Electrical Conductivity (EC), organic C, available $\mathrm{N}, \mathrm{P}$, $\mathrm{K}$ and $\mathrm{Zn}$ values. Relevant physical and chemical properties were determined following standard analytical procedures (Jackson, 1973; USDA, 1980). Randomly selected 50 plots were selected for soil sample collection located in the five villages. The soil samples, with a depth of $45 \mathrm{~cm}$, were collected in end of the Rabi season of India during May 2015 (Soil Survey Staff, 2000). The soil samples are dried, cursed and passed through a $2 \mathrm{~mm}$ sieved screen. The samples have been undergone laboratory analysis for selected parameters, such as: $\mathrm{pH}$, soil texture, EC, organic $\mathrm{C}$, available $\mathrm{N}, \mathrm{P}, \mathrm{K}$ and $\mathrm{Zn}$, following standard laboratory soil analysis procedures. Soil texture of soil samples was determined by estimating percentage of sand, silt and clay according to USDA system by Hydrometer method (Piper, 1942). The class of soil texture was determined by USDA method. Using textural triangle diagram (USDA, 1980). The readings were estimated in parts per million (PPM) scale.

\subsection{Selection of evaluation criteria}

Evaluation criteria objectives and attributes need to be identified with respect to the particular situation under consideration. In land suitability analysis, each evaluation criterion is represented by a separate map in which a 'degree of suitability' with respect to that particular criterion is 
ascribed to each unit of area (Sehgal, 1996; Prakash, 2003). These 'degrees of suitability' then need to be rated according to the relative importance of the contribution made by that particular criterion, towards achieving the ultimate objective. Agricultural Land suitability studies were described by a set of land us requirements or land quality parameters, which are the land conditions necessary for successful farming, while land mapping or point units were described by a set of land characteristics, which are land attributes that influence their suitability for given land utilization types Van Diepen et al. (1991). In this study, eight main criteria, that are, $\mathrm{pH}$, soil texture EC,OC, available nitrogen, available phosphorous, available potassium, and available zinc and weighting rates normally employed in jute and lentil growing site suitability evaluation were used to compile information on the study area.

\subsection{Weightage analysis in AHP}

Being a biological entity, opinions of ten experts, in the field of agronomy and soil science related to agriculture in general, were sort for ranking the relative importance of crop nutrients for a particular crop (i.e. jute, and lentil). In this investigation, the evaluation criteria were selected taking into considering the crop requirements regarding local conditions. In this MCA, the factors were selected based on agronomic knowledge of local experts and reviews of existing literature (Kritikos and Davies, 2011; Yalew et al., 2016). Specific efforts were made to get agreement on ranking of the parameters. Utilizing the ranking parameters and AHP guidelines, pairwise comparison matrix for each crops are estimated. Using this process to standardize the criterion maps, first a pairwise comparison matrix for suitability classes (i.e. $\mathrm{S}_{1}, \mathrm{~S}_{2}, \mathrm{~S}_{3}$ and $\mathrm{N}$ ) was prepared and the eigenvector of weights was calculated for each class. The weightage of each parameter were calculated using AHP technique (Saaty, 1977). For eight parameters, random inconsistency index (RI) was taken (Saaty and Vargas, 1991). Principal Eigenvalue $\left(\lambda_{\max }\right)$ and Consistency Index $(\mathrm{Cl})$ were estimated. Then Consistency ratio (CR) was estimated to validate the estimated weightage values (Saaty and Vargas, 1991). Some studies (Aimrun et al., 2011) has followed the impact of individual parameters on crop yield, to defined their importance. However, the impact of single parameter on the crop yield is minimal and the regression curves are very insignificant. Hence, the technique was not followed (Ahamed et al., 2000; Tabi et al., 2012). The AHP weightage for lentil and jute crop are estimated using Saaty (1980) technique (Tables 1 and 2). The $\mathrm{pH}$ is highest ranked for jute crop and

Table 1: Pair wise comparison matrix and eigenvector of criteria in AHP for jute crop $(n=8)$

\begin{tabular}{lccccccccc}
\hline & $\mathrm{pH}$ & $\mathrm{ST}$ & $\mathrm{N}$ & $\mathrm{Zn}$ & $\mathrm{OC}$ & $\mathrm{EC}$ & $\mathrm{P}$ & $\mathrm{K}$ & Weightage \\
\hline $\mathrm{pH}$ & 1 & 2 & 3 & 4 & 5 & 5 & 6 & 7 & 0.317 \\
$\mathrm{ST}$ & 0.5 & 1 & 2 & 3 & 4 & 4 & 5 & 6 & 0.218 \\
$\mathrm{~N}$ & 0.333 & 0.5 & 1 & 2 & 4 & 4 & 5 & 5 & 0.165 \\
$\mathrm{Zn}$ & 0.25 & 0.333 & 0.5 & 1 & 2 & 2 & 4 & 5 & 0.105 \\
$\mathrm{OC}$ & 0.2 & 0.25 & 0.25 & 0.5 & 1 & 1 & 3 & 5 & 0.072 \\
$\mathrm{EC}$ & 0.2 & 0.25 & 0.25 & 0.5 & 1 & 1 & 2 & 3 & 0.06 \\
$\mathrm{P}$ & 0.167 & 0.2 & 0.2 & 0.25 & 0.333 & 0.5 & 1 & 2 & 0.037 \\
$\mathrm{~K}$ & 0.142 & 0.167 & 0.2 & 0.2 & 0.2 & 0.333 & 0.5 & 1 & 0.026 \\
\hline
\end{tabular}

Note: $\lambda_{\max }=8.53 ; \mathrm{RI}: 1.41 ; \mathrm{Cl}: 0.08 ; \mathrm{CR}: 0.05(<0.10) ; \mathrm{ST}$ : soil Texture; OC: Organic carbon; N: Avilable nitrogen; P: available phosphorous; K: Available potassium; Zn: Zinc level; n: Number of parameters

Table 2: Pair wise comparison matrix and eigenvector of criteria in AHP for lentil crop $(n=8)$

\begin{tabular}{lccccccccc}
\hline & $\mathrm{ST}$ & $\mathrm{pH}$ & $\mathrm{Zn}$ & $\mathrm{EC}$ & $\mathrm{OC}$ & $\mathrm{P}$ & $\mathrm{K}$ & $\mathrm{N}$ & Weightage \\
\hline $\mathrm{ST}$ & 1 & 2 & 3 & 5 & 6 & 7 & 8 & 8 & 0.345 \\
$\mathrm{pH}$ & 0.5 & 1 & 2 & 3 & 3 & 5 & 7 & 8 & 0.218 \\
$\mathrm{Zn}$ & 0.333 & 0.5 & 1 & 2 & 3 & 4 & 5 & 7 & 0.153 \\
$\mathrm{EC}$ & 0.2 & 0.333 & 0.5 & 1 & 2 & 3 & 5 & 6 & 0.107 \\
OC & 0.167 & 0.333 & 0.333 & 0.5 & 1 & 2 & 4 & 5 & 0.077 \\
$\mathrm{P}$ & 0.142 & 0.2 & 0.25 & 0.333 & 0.5 & 1 & 2 & 3 \\
$\mathrm{~K}$ & 0.125 & 0.142 & 0.2 & 0.2 & 0.25 & 0.5 & 1 & 3 \\
$\mathrm{~N}$ & 0.125 & 0.125 & 0.142 & 0.167 & 0.2 & 0.333 & 0.333 & 0.033 \\
\hline
\end{tabular}

Note: $\lambda_{\max }=8.53 ; \mathrm{RI}: 1.41 ; \mathrm{Cl}: 0.08 ; \mathrm{CR}: 0.05(<0.10) ; \mathrm{ST}$ : soil Texture; OC: organic carbon; N: Avilable nitrogen; P: available phosphorous; K: Available potassium; Zn: Zinc level 
soil texture for lentil crop. Nitrogen is given least importance for lentil crop.

\section{Results and Discussion}

The study area map was developed in GIS software environment showing various features of the area such as road network, canal distribution, railway tracks etc (Figure 1 and 2). It will give general idea of the surrounding of the study area. With canals around, there is irrigation facilities for growing different crops.

Pairwise weightage was given as per the AHP technique

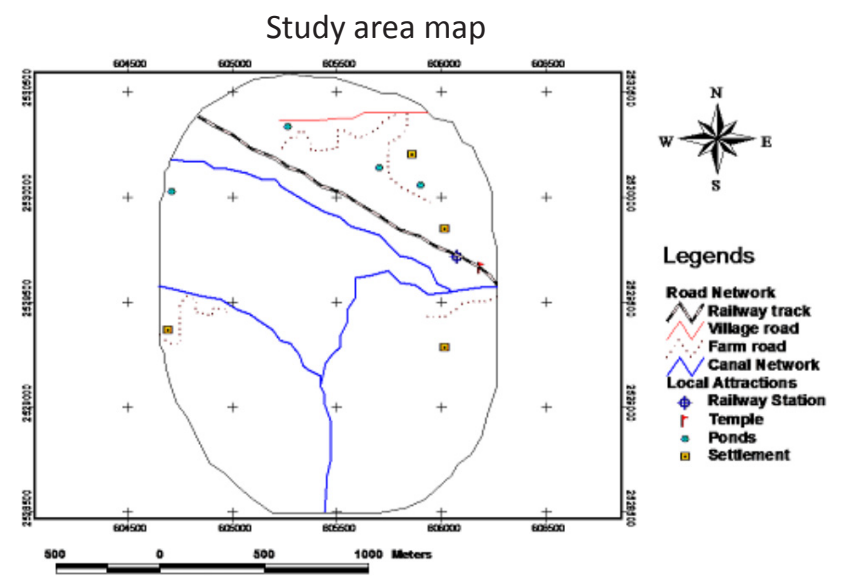

Figure 1: Study area map

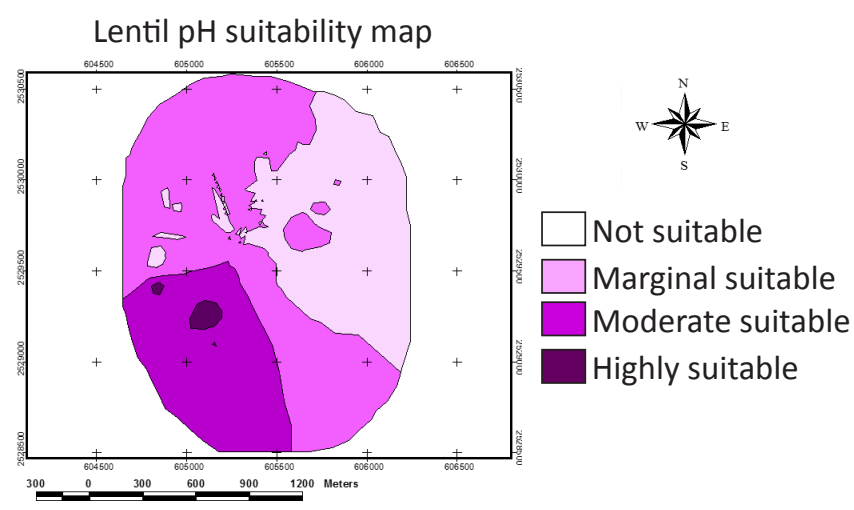

Lentil pH suitability map-deep layer

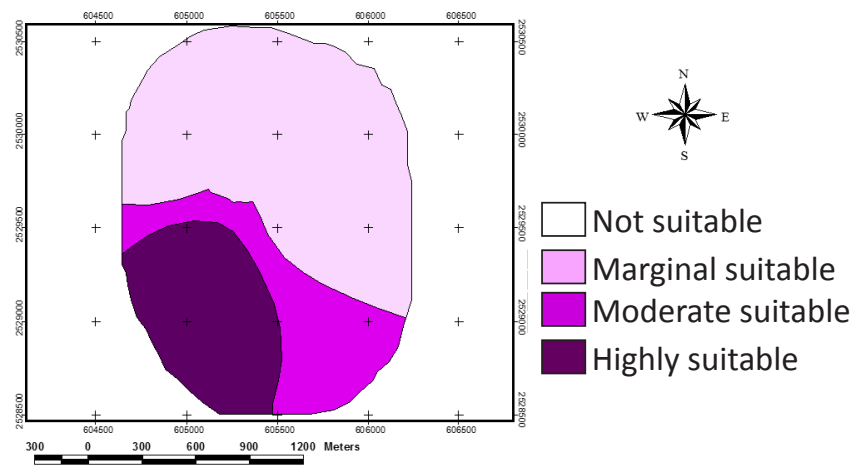

(Saaty, 1980) to each soil parameters. The final weightage of individual parameter for jute and lentil was estimated in Matlab software application (Tables 1 and 2).

AHP technique is one of few techniques for giving wieghtage in suitability analysis, where the validity of weightage are checked mathematically. When the values do not validate the limiting criteria, they has to be rearranged and validated again. The Consistency ratio (CR) of 0.05 for jute and CR of 0.06 for lentil are well within the limit of 0.10 ; So the weightage assigned for individual parameters are valid and can be used further for suitability analysis. As usual the parmeter ranked 1st gets the highest weightage i.e. $\mathrm{pH}$ of jute assigned highest weightage of 0.317 and Soil texture of lentil assigned highest weightage of 0.345 .

\subsection{Jute crop}

\subsubsection{Top layer}

Jute is an important major deep rooted cash crop during summer, grown under irrigated condition in the study area. As per the suitability analysis, nearly $6.5 \%$ of farm area is classified as 'highly suitable' $\left(\mathrm{S}_{1}\right)$; $56 \%$ area is 'moderate suitable' $\left(\mathrm{S}_{2}\right)$ and nearly $2.1 \%$ area is 'not suitable' $(\mathrm{N})$ (Table $3)$. These areas comes under jute cropping belt of the region as per the annual crop output statistics. Here $95 \%$ of the land area was fallen under suitable range (Figure 3 ). The major suitability limitations reported for these soils were low organic carbon and nitrogen contents with high acidic $\mathrm{pH}$.

Jute zinc suitability map

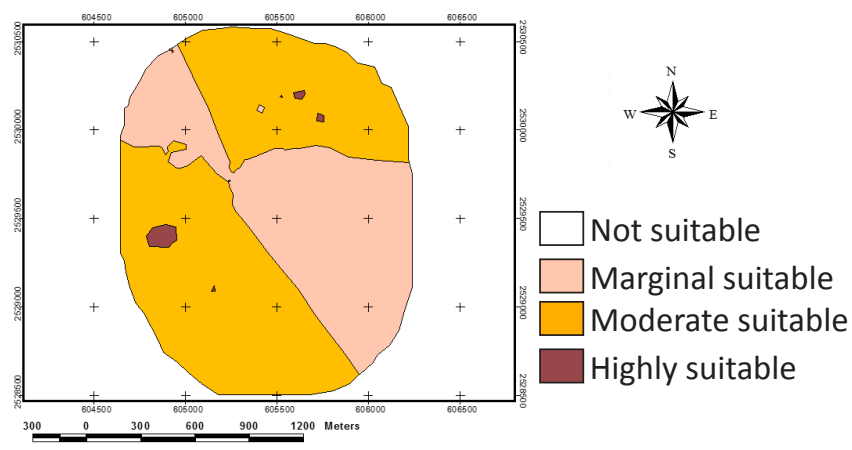

Jute zinc suitability map-deep layer

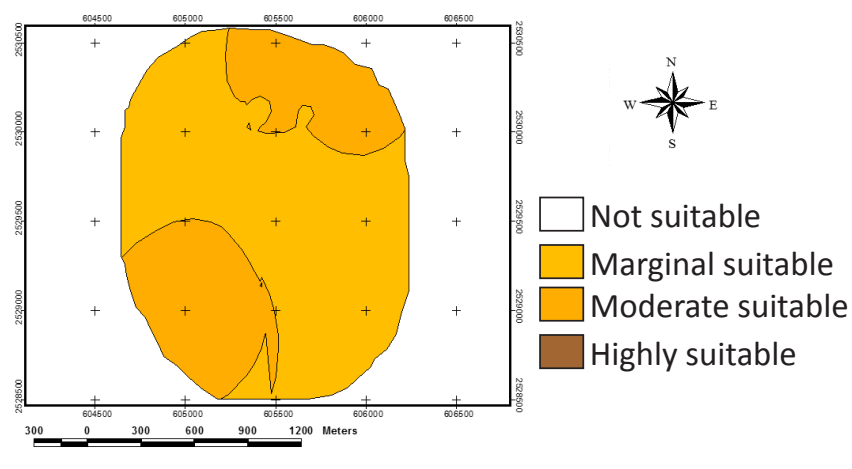

Figure 2: Suitability maps of $\mathrm{pH}$ for lentil and zinc for jute crop for soil layers 


\begin{tabular}{llcc}
\hline \multicolumn{2}{c}{ Table 3: Land suitability class for jute crop of the study area } \\
\hline class & \multicolumn{2}{c}{ Description } & \multicolumn{2}{c}{ Jute (\% of area) } \\
\cline { 3 - 4 } & & Top layer & Deep layer \\
\hline $\mathrm{S}_{1}$ & Highly suitable & 6.5 & 10.3 \\
$\mathrm{~S}_{2}$ & Moderate suitable & 56.0 & 26.5 \\
$\mathrm{~S}_{3}$ & Marginal suitable & 35.4 & 52.2 \\
$\mathrm{~N}$ & Not suitable & 2.1 & 11.0 \\
\hline
\end{tabular}

Lentil suitable area distribution map

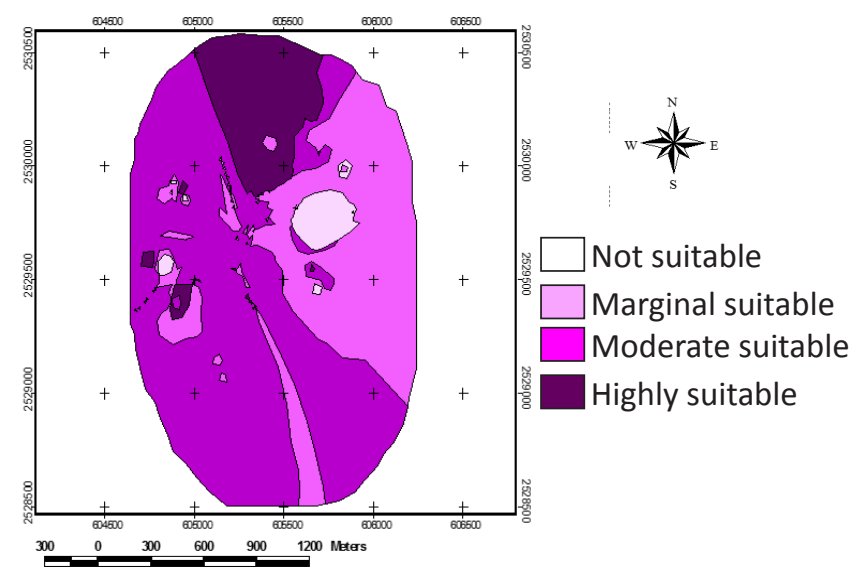

a) top layer

Lentil suitable distribution map-deep layer

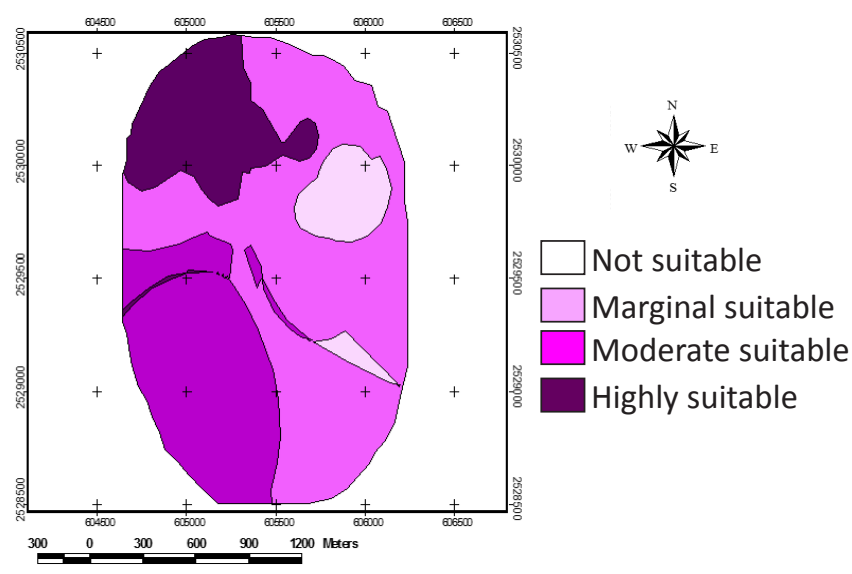

b) deep layer

Figure 3: Land suitability class for Lentil crop of study area a) top layer b) deep layer

\subsubsection{Deep layer}

Jute is capable to bring up the basic cataions from subsoil and deposit them on the surface, as litter may be one remedy for reducing surface acidity and increasing various micro and macro-nutrient availabilities. It requires higher soil depth and precipitation compared to other deep rooted crops. During drought period, crops on shallow soil are usually the first to show stress because of lack of moisture in the upper soil layer. For better management of deep rooted crop, deep layer suitability analysis was carried out. The study revealed that the $10.3 \%$ of the study area is 'highly suitable' $\left(\mathrm{S}_{1}\right)$ and nearly $52.2 \%$ are is 'marginally suitable' $\left(\mathrm{S}_{3}\right)$, and around $11.0 \%$ area und 'not suitable' (N) for jute crop. Marginal suitability of deep soil layer may be attributed from increasing irrigation to salinity and other pedogenic process modified by water table distribution (Figure 3).

Additionally, it is important to point out that there will always be an element of subjectivity when applying expert judgment for determining weight of factors. To solve this problem this study has demonstrated that the AHP is best alternative to determine the criteria weights from judgments of decisionmaking domain of experts (Duc, 2006).

\subsection{Lentil crop}

\subsubsection{Top layer}

Lentil is also an important pulses crop growing in Tarakeswar block, West Bengal. It may be tried as an alternative crop for the area unsuitable for jute crop. Lentil suitability distribution map was developed for top layer using AHP weightage in GIS environment (Figure 4). The analysis revealed that (Table

Jute suitability area distribution map

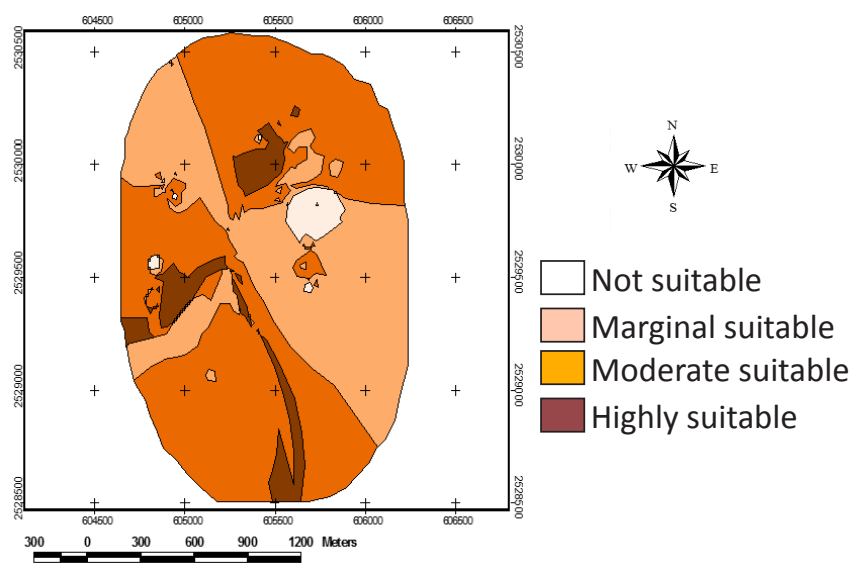

a) top layer

Jute suitability distribution map-deep layer

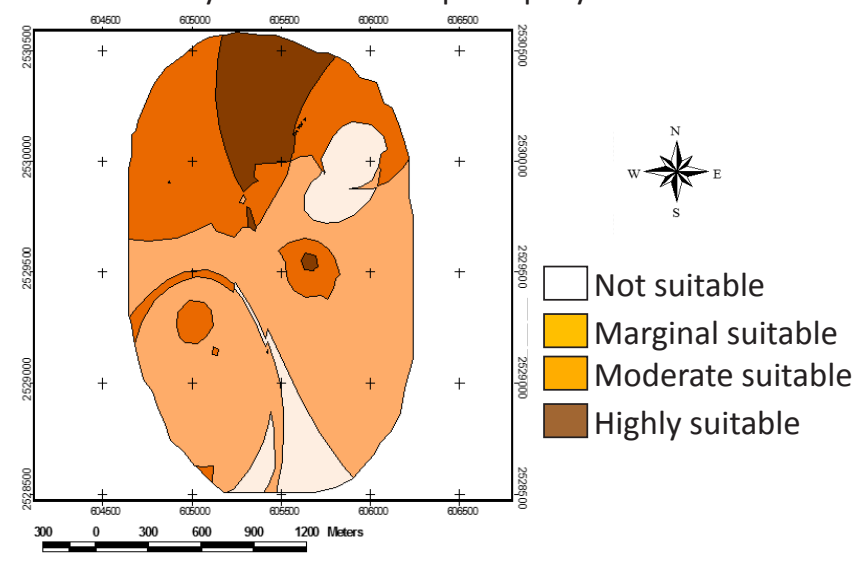

b) deep layer

Figure 4: Land suitability class for Jute crop of study area a) top layer b) shallow layer c) deep layer 
4) around $12.4 \%$ of total lentil crop is in 'highly suitable' $\left(\mathrm{S}_{1}\right)$ zone, $54.6 \%$ area is in 'moderately suitable' $\left(\mathrm{S}_{2}\right)$ zone. A substantial portion (30\%) was under 'marginal suitable' $\left(\mathrm{S}_{3}\right)$ zone and $3 \%$ was under 'not suitable' $(N)$ zone. Together, the two categories 'highly suitable' and moderate 'suitable' make up $67 \%$ of the total area may be dedicated for lentil crop, if jute is not profitable in the area.

\begin{tabular}{llcc}
\hline \multicolumn{2}{c}{ Table 4: Land suitability Class for lentil crop of the study area } \\
\hline \multirow{2}{*}{ class } & Description & \multicolumn{2}{c}{ Lentil (\% of area) } \\
\cline { 3 - 4 } & & Top layer & Deep layer \\
\hline $\mathrm{S}_{1}$ & Highly suitable & 12.4 & 15.8 \\
$\mathrm{~S}_{2}$ & Moderate suitable & 54.6 & 26.8 \\
$\mathrm{~S}_{3}$ & Marginal suitable & 30.0 & 50.2 \\
$\mathrm{~N}$ & Not suitable & 3.0 & 7.2 \\
\hline
\end{tabular}

\subsubsection{Deep layer}

Suitability map for lentil crop in the deep soil layer is also carried out using the AHP weightage in GIS environment (Fig. 4). The analysis showed that $15.8 \%, 26.8 \%, 50.2 \%$, and $7.2 \%$ of lands (Table 4) are classified as $\mathrm{S}_{1}, \mathrm{~S}_{2}, \mathrm{~S}_{3}$, and $\mathrm{N}$ suitability classes, respectively, for lentil crop. Area under 'marginal suitability' $\left(\mathrm{S}_{3}\right)$ is enhanced drastically showing low level of nutrient availability in the deep soil layer.

A widely accepted modelling framework is the Analytical Hierarchy Process (AHP), which has been extensively applied for MCA purposes and utilised in many decision-making problems (Akinici et al., 2013). However, any methods that are employed to make these suitability determinations can be subject to uncertainties in both the scope and quality of outputs. Consequently, the results obtained from this study indicated that the use of AHP technique in GIS environment could provide a superior database and guide map for decision makers for adopting precision agriculture for deep rooted crop (jute and lentil etc.). With both top layer and bottom soil layer, suitability maps, best area for growing lentil crop can be easily identified in the study area.

\section{Conclusion}

AHP-GIS technique is used for land suitability study in Hooghly, West Bengal for existing jute and lentil for a study are of 300 ha using Pairwise comparison matrix based ranking. The area, being under major jute production zone, classified in top layer as 'moderate suitable' class 56\% and 'not suitable' class $2.5 \%$; on deep layer, lentil crop area is classified 'marginal suitable' class $50.2 \%$, and 'not suitable' class $7.2 \%$. The AHP-GIS technique should used for crop selection and crop rotation analysis.

\section{References}

Ahamed, T.R.N., Rao, K.G., Murthy, J.S.R., 2000. GIS-based fuzzy membership model for crop-land suitability analysis. Agricultural Systems 63, 75-95.

Aimrun, W., Amin, M.S.M., Ezrin, M.H., Mastura, M., 2011. Paddy soil properties and yield characteristics based on apparent electrical conductivity zone delineation for a humid tropical rice farm. African Journal of Agricultural Research 6(23), 5339-5350.

Akinci, H., Ozalp, A.Y., Turgut, B., 2013. Agricultural land use suitability analysis using GIS and AHP technique. Computers and Electronics in Agriculture 97, 71-82.

Bag, S.N., Kumar, U.C., Pal, A.K., 2015. Challenges, threats and opportunities of jute industry-A review. Man-Made Textiles in India 43(10), 385-391.

Baja, S., Chapman, D.M., Dragovich, D., 2007. Spatial based compromise programming for multiple criteria decision making in land use planning. Environmental Modelling and Assessment 12, 171-184.

Cengiz, T., Akbulak, C., 2009. Application of analytical hierarchy process and geographic information systems in land-use suitability evaluation: a case study of Dumrek village. International Journal of Sustainable Development and World Ecology 16(4), 286-294.

Chen, H., Liu, G., Yang, Y., Ye, X., Shi, Z., 2010. Comprehensive evaluation of tobacco ecological suitability of Henan Province based on GIS. Agricultural Sciences in China 9(4), 583-592.

Duc, T.T., 2006. Using GIS and AHP technique for land-use suitability analysis. In: International symposium on geo-informatics for spatial infrastructure development in earth and allied sciences, 1-6.

Elsheikh, R., Rashid, B.A., Shariff, M., Amiri, F., Ahmad, N B., Balasundram, S.K., Amin, M., Soom, M., 2013. Agriculture land suitability evaluator (ALSE): A decision and planning support tool for tropical and subtropical crops. Computers and Electronics in Agriculture 93, 98-110.

FAO, 1985. Guidelines: Land evaluation for irrigated agriculture, FAO Soils bulletin 55. Rome, Italy.

FAO, 1993. A frame work for land suitability study for irrigated agriculture, Rome, Italy.

He, Y., Yao, Y., Chen, Y., Ongaro, L., 2011. Regional land suitability assessment for tree crops using remote sensing and GIS. Computer Distributed Control and Intelligent Environmental Monitoring (CDCIEM) IEEE, Changsha, 354-363.

Jackson, M.L., 1973. Soil chemical analysis. Prentice Hall of India Pvt. Ltd, New Delhi.

Javadian, M., Shamskooshki, H., Momeni, M., 2011. Application of sustainable urban development in environmental suitability analysis of educational land use by using AHP and GIS in Tehran. Procedia Engineering 21, 72-80.

Kekane, M.A., 2013. Indian agriculture-status, importance and role in Indian economy. International Journal of Agriculture and Food Science Technology 4(4), 343-346. Khahro, S.H., Matori, A.N., Chandio, I.A., Talpur, M.A.H., 2014. 
Land suitability analysis for installing new petrol filling stations using GIS. Procedia Engineering 77, 28-36.

Kritikos, T., Davies, T.R.H., 2011. GIS-based multi-criteria decision analysis for landslide susceptibility mapping at northern Evia, Zeitschrift der Deutschen Gesellschaft für Geowissenschaften 162(4), 421-434.

Kumar, R., 2017. Indian jute industry and its future. International Journal of Business and General Management (IJBGM) 6(4), 21-32.

Lee, T.M., Yeh, H.C., 2009. Applying remote sensing techniques to monitor shifting wetland vegetation: a case study of Danshui River estuary mangrove communities, Taiwan. Ecological Engineering 35, 487-496.

Martin, D., Saha, S.K., 2009. Land evaluation by integrating remote sensing and GIS for cropping system analysis in a watershed. Current Science 96(4), 569-575.

Martinez-Casasnovas, J.A., Martin-Montero, A., Casterad, M.A., 2005. Mapping multi-year cropping patterns in small irrigation districts from time-series analysis of Landsat TM images. European Journal of Agronomy 23(2), 159-169.

Mu, Y., 2006. Developing a suitability index for residential land use: A case study in dianchi drainage area. University of Waterloo, Canada.

NBBS, LUP., 2001. Soil series of West Bengal, NBSS publ. no. 89. NBSS and LUP (ICAR), Nagpur, 38-40.

NCP, 2013. Projected population characteristics, India, Ministry of health and family welfare. Government of India. Available from: https://data.gov.in/catalog/ projected-population-characteristics.

Panigrahy, S., Ray, S.S., Sharma, P.K., Sood, A., Patel, L.B., 2004. Analysis of cropping pattern changes in Bathinda district, Punjab. Journal of the Indian Society of Remote Sensing 32(2), 209-216.

Perveen, M.F., Nagasawa, R., Uddin, M.I., Delowar, H.K.M., 2007. Crop-land suitability analysis using a multicriteria evaluation \& GIS approach. In: $5^{\text {th }}$ International Symposium on Digital Earth (ISDE5), University of California, Berkeley, USA.

Piper. C.S., 1942. Soils and plant analysis. Yhe university of Adelaide; Adelaide, 368.

Prakash, T., 2003. Land suitability analysis for agricultural crops: a fuzzy multicriteria decision making approach.
International institute for geo-information science and earth observation enschede, 6-13.

Saaty, T.L., Vargas, L.G., 1991. Prediction, Projection and Forecasting. Kluwer, Boston, MA.

Saaty, T.L., 1977. A scaling method for priorities in hierarchical structures. Journal of Mathematical Psychology 15(3), 234-281.

Sehgal, J., 1996. Pedology concepts and applications. Kalyani Publishers, Ludhiana, 258.

Singh, K.M., Singh, A., 2014. Lentil in India: An Overview. Available at SSRN: https://ssrn.com/abstract=2510906 or http:// dx.doi.org/10.2139/ssrn.2510906

Singha, C., Swain, K.C., 2016. Land suitability evaluation criteria for agricultural crop selection: A Review. Agricultural Reviews 37(2), 125-132.

Soil Survey Division Staff, 2000Soil. Survey Manual (Indian Print), Hb. No.IS, USDA, Washington, D.C.

Sonneveld, M.P.W., Hack-ten Broeke, M.J.D., van Diepen, C.A., Boogaard, H.L., 2010. Thirty years of systematic land evaluation in the Netherlands. Geoderma 156, 84-92.

Sood, A., Ray, S.S., Choudhury, B.U., Sharma, P.K., Panigrahy, S., 2017. Long term changes in cropping pattern of bathinda district, punjab-A remote sensing approach, www.isprs.org/proceedings/XXXVI/part4/RS-A9.

Tabi, F.O., Omoko, M., Boukong, A., Mvondo Ze, A.D., Bitondo, D., Fuh Che, C., 2012. Evaluation of lowland rice (Oryza sativa) production system and management recommendations for logone and chari flood plainrepublic of cameroon. Agricultural Science Research Journals 2(5), 261-273.

USDA, 1980. Agricultural research service, soil texture classification, department of biological system engineering, Washington State University, USA.

Van Diepen, C.A., Van Keulen, H., Wolf, J., Berkhout, J.A., 1991. Land evaluation: from intuition to quantification. In: Stewart, B.A. (Ed.), Advances in Soil Science. Springer, New York, 139-204.

Yalew, S.G., van Griensven, A., Mul, M.L., Zaag, P.V., 2016. Land suitability analysis for agriculture in the Abbay basin using remote sensing, GIS and AHP techniques. Modelling Earth Systems and Environment 2, 101. 